\title{
The Acquisition of Practical Skills in Nursing Students. A Challenge in Primary Health Care
}

\author{
Mayle Santana Hernández ${ }^{1}$, Claribel Plain Pazos ${ }^{2}$, Carmen Rosa Carmona Pentón ${ }^{2}$, Anisbel \\ Pérez de Alejo Plain ${ }^{3}$, Yaquelín Martínez Chávez ${ }^{4}$, Lianet Corne Sosa ${ }^{5}$ \\ ${ }^{1}$ Bachelor of Nursing, Assistant Professor, Faculty of Medical Sciences of Sagua la Grande, Villa \\ Clara, Cuba \\ ${ }^{2}$ Specialist of I and II Degree in Comprehensive General Medicine, Assistant Professor, Faculty of \\ Medical Sciences of Sagua la Grande, Villa Clara, Cuba \\ ${ }^{3} 4$ th Year Student of Medicine, Faculty of Medical Sciences of Sagua la Grande. Villa Clara, Cuba \\ ${ }^{4}$ Specialist of I Degree in Pharmacology, Assistant Professor, Faculty of Medical Sciences of Sagua la \\ Grande, Villa Clara, Cuba \\ ${ }^{5} 3$ th Year Student of Medicine, Faculty of Medical Sciences of Sagua la Grande. Villa Clara, Cuba \\ *Corresponding Author: Claribel Plain Pazos, Specialist of II Degree in Comprehensive General \\ Medicine, Assistant Professor, Faculty of Medical Sciences of Sagua la Grande, Villa Clara, Cuba.
}

\section{OPINION ARTICLE}

The acquisition of practical skills in nursing students is a need and at the same time a challenge in Primary Health Care (PHC).

In 1978, the International Conference of AlmaAta defined PHC as the strategy to meet the goal of "Health for All by the year 2000", and is understood as: ... Essential healthcare based on practical methods and technologies, scientifically founded and socially acceptable, made available to all individuals and families in the community through their full participation and at a cost that the community and the country can bear in each and every stage of their development with a spirit of responsibility and self-determination. PHC is an integral part of the National Health System (SNS), of which it constitutes the central function and the main nucleus of the global social and economic development of the community. It represents the first level of contact of the SNS with individuals, the family and the community [1].

Nursing is a profession of the health sciences, whose object of study is nursing care for the person, the family, the community and the environment. It deals with diagnosing and treating individual and collective responses to the manifestations of the health-disease process in the area of its competences, applying the logic of the Nursing Care Process as the scientific method of the profession; taking into account promotion, prevention, healing and rehabilitation actions to guarantee physical, mental and social well-being. It also uses the teaching, administrative and investigative processes to guarantee the quality and optimization of nursing services, in the search for excellence. The fundamental principles that sustain training are the priority of aspects of an educational nature in the training process, in close and indissoluble unity with the instructions and the link between study and work, which has historically been specified in science careers Doctors in the adoption of education at work as a fundamental educational organizational form [2].

The teaching scenario of the APS meets the structural requirements to face teaching in the acquisition of practical skills of nursing students, since it has a network of medical offices located in the community itself to which it provides health services, thus guaranteeing education at work in the care setting itself.

The progressive technological development fosters numerous challenges that require a growing qualification that allows them to face the constant demands, in the different areas of knowledge, therefore, the levels of demand point towards greater professionalization, the trend is to train a professional profile broad based on education at work, which responds to the current challenges of society and the health system. PHC constitutes a benchmark for this fusion in the educational process that responds to three methodological axes [3].

- Linking study with work and theory with practice through the academic version of education at work. 
- The integration of teaching care research.

- The pedagogical methods of the teachinglearning process are the methods of professional work, which are scientifically structured.

- Combine study and work.

The teaching-care teacher is very important because the number of hours that the student will stay in the clinics developing activities of Education at Work is high, which should contribute to their technical training and will allow them to work in different institutions of the health system as well as continue studying at the professional level.

It is in education at work where, under the supervision of the tutor and with the prior informed consent of the patient, the students observe and carry out the different techniques or procedures that, according to the skills card declared in their study plan, they must execute. These procedures must be carried out taking into account the principles of bioethics such as: beneficence and non-maleficence.

The practical skills that the student must complete, according to his study plan according to the year of the career in which he is working, must be carried out as many times as possible and the mastery of the contents must be reflected by the tutor or assisting teaching teachers of the offices on the skills control card that each student has.
It is a challenge for the teaching staff to bring their two functions of teaching and assistance together, to ensure that their students acquire the necessary skills declared in their study plan without losing quality in their care function.

The quality of the student depends directly on the quality of the teaching staff. Education at Work is the primary educational organizational form for the acquisition of practical skills in PHC.

\section{REFERENCES}

[1] Serrano Díaz CA, Carrillo Alfonso TM, Santamaría Machín W, Cordero Paz I, Espinosa Martínez K. Metodología para el pase de visita de Enfermería en la atención primaria de salud. Rev Méd Electrón [Internet]. 2018 Jul-Ago [citado: fecha de acceso];40(4). Disponible en: http://www.revmedicaelectronica. sld.cu/index.php/rme/article/view/2276/3985

[2] Ministerio de Salud Pública. Plan de estudio" D".2010

[3] Vialart MN, Rodríguez EI, Véliz PL, Suárez A, et al. Tendencias actuales de programas de estudio de pregrado y posgrado con orientación a la Atención Primaria de la Salud. Educ Médic Superior [Internet]. 2016 [citado 16 Feb 2018]; 30(3). Disponible en: http://www.ems. sld.cu/ index.php/ems/article/view/839

[4] Programa Analítico de la Asignatura: Fundamentos de Enfermería .CRD.2014

Citation: Mayle Santana Hernández et al, "The Acquisition of Practical Skills in Nursing Students. A Challenge in Primary Health Care", International Journal of Research Studies in Medical and Health Sciences. 2020; 5(10): 9-10.

Copyright: () 2020 Mayle Santana Hernández et al,, This is an open-access article distributed under the terms of the Creative Commons Attribution License, which permits unrestricted use, distribution, and reproduction in any medium, provided the original author and source are credited. 